\title{
Dr. MERKL OTTÓ emlékezete (1957-2021)
}

\author{
SZÉL GYőZő \\ Magyar Természettudományi Múzeum, Állattár, 1088 Budapest, Baross u. 13. \\ E-mail: szel.gyozo@nhmus.hu
}

2021. február 19-én, 64 éves korában elhunyt Dr. MERKL OTTÓ zoológus, entomológus, a Magyar Természettudományi Múzeum főmuzeológusa, a hazai rovartan kiemelkedő alakja, a katicabogarak (Coccinellidae) és a gyászbogarak (Tenebrionidae) nemzetközileg is elismert szakértője. Személyében egy sokoldalú, nagy müveltségü, fáradtságot nem ismerő természettudós távozott közülünk, aki muzeológusként a tudományban és az ismeretterjesztésben egyaránt maradandót alkotott (VIG 2020, 2021).

\section{Életútja}

MERKL OTTÓ 1957. augusztus 26-án született Budapesten. Felesége KISS KLÁRA, biológia-kémia szakos tanárnő a budapesti Vörösmarty Mihály Gimnáziumban. Két lányuk született, DóRA (1986) és BOGLÁRKA (1991). Középiskolai tanulmányait 1971 és 1975 között végezte a Kaffka Margit Gimnázium biológia tagozatán, ahol 1975-ben érettségizett. Ugyanebben az évben első helyezést ért el biológiából az Országos Középiskolai Tanulmányi Versenyen, így felvételi vizsga nélkül jutott be az Eötvös Loránd Tudományegyetemre. OTTÓ 1981. szeptember 1-én került a múzeumba, ahol közel 40 évig, haláláig dolgozott. A kiváló entomológus és múzeumi főigazgató KASZAB ZOLTÁN (1915-1986) nyugdíjba menetele (1985) után MERKL OTTÓ lett a 3 millió példányt számláló, európai mércével is jelentős Bogárgyüjtemény vezetője. Gyüjteményvezetői pozíciója mellett 2021 februárjában kinevezték az Állattár igazgatójának.

\section{Múzeumi munkája}

A 7000 múzeumi rovardobozból álló, kétharmadában Kárpát-medencei (ezen belül is főként magyarországi), egyharmadában a Föld más tájairól származó gyüjtemény gondozása, bővítése, rendezése és fejlesztése képezte MERKL OTTÓ múzeumi munkájának legfontosabb részét. A budapesti múzeum bogárgyűjteménye valójában nem is a nagysága, hanem az Európából és Ázsiából leírt fajok típuspéldányainak magas száma miatt lett híres és úgyszólván nélkülözhetetlen a bogarak taxonómiájával foglalkozó kutatók számára. Kiemelkedően fontos a gyászbogárgyüjtemény, amelyben több mint 6000 faj, illetve alfaj van típuspéldányokkal képviselve. A külföldről érkező megkeresések, kérések zöme éppen a gyász- 
bogarakat érinti, melynek során többnyire típuspéldányokat vagy újabban azok fotóit kérik. A kölcsönzések precíz és haladék nélküli teljesítése révén OTTó világszerte nagy megbecsülésnek örvendett a bogarászok körében.

\section{Tudományos tevékenysége}

MERKL OTTÓ pályafutásának kezdeti szakaszában specialistaként főként katicabogarakkal foglalkozott, 1982-ben elkészített egyetemi doktori dolgozata (Taxonómiai és faunisztikai vizsgálatok a Kárpát-medence katicabogár (Coleoptera: Coccinellidae) faunáján) is ezt a csoportot dolgozza fel. A határozókulcsokat, rajzokat és elterjedési térképeket tartalmazó (de sajnos sohasem publikált) munka a Magyarország Állatvilága (Fauna Hungariae) akadémiai kiadványsorozat felfogását követi, és a hazai katicabogarak máig legteljesebb ismertetésének tekinthető. Itt jegyzem meg, hogy 2008-ban MERKL OTTÓ mutatta ki Magyarországról az inváziós harlekinkaticát (Harmonia axyridis; az első példány lelőhelye Szigetszentmiklós), és számos közleményében, online írásaiban sokszor kitért erre a veszélyes jövevényfajra.

Később, részben KASZAB ZOLTÁN tanácsára, részben a múzeumi gyüjtemény adta páratlan lehetőségeket kihasználva a gyászbogarak, azon belül is a gyapjasbogarak (Lagriinae) kerültek kutatásainak homlokterébe. (E fehér foltnak számító csoportot korábban Lagriidae néven önálló családként emlegették, ma a gyászbogarakhoz tartozik.) 1995-ben megvédett, „Taxonómiai és muzeológiai feladatok megoldása a Magyar Természettudományi Múzeum Bogárgyüjteményében" című kandidátusi disszertációjának tekintélyes része is a gyász-, illetve gyapjasbogarak taxonómiájáról szól (SzÉL 2021b).

MERKL OTTÓ összesen 18 új gyászbogár-nemzetséget, valamint 164 tudományra új fajt és alfajt írt le, zömmel gyapjas- és gyászbogarakat Ausztráliából, Új-Guineából, illetve az indomaláj állatföldrajzi régióból, amelyeket többnyire nagyobb lélegzetű revíziós müvekben tett közzé. E leíró munka elvégzéséhez több mint 200 intézményből, múzeumból, valamint magánszemélyektől kapott bogárpéldányokat. Jelentős a 2015-ben, KASZAB ZOLTÁN születésének 100. évfordulóján megjelent 735 oldal terjedelmü gyászbogártípus-katalógus, melyet GRABANT ARANKÁval és SOLTÉSz ZOLTÁNnal társszerzőségben írt. A hiánypótló munkában az Állattár Bogárgyüjteményében fellelhető összes típuspéldány szerepel. Utolsó, de talán legjelentősebb tudományos munkája (Review of genus-group names in the family Tenebrionidae (Insecta: Coleoptera)), a világ gyászbogarainak genusz-katalógusa már halála után, 2021-ben jelent meg. MERKL OTTÓ összesen 248 tudományos közleményt publikált. 


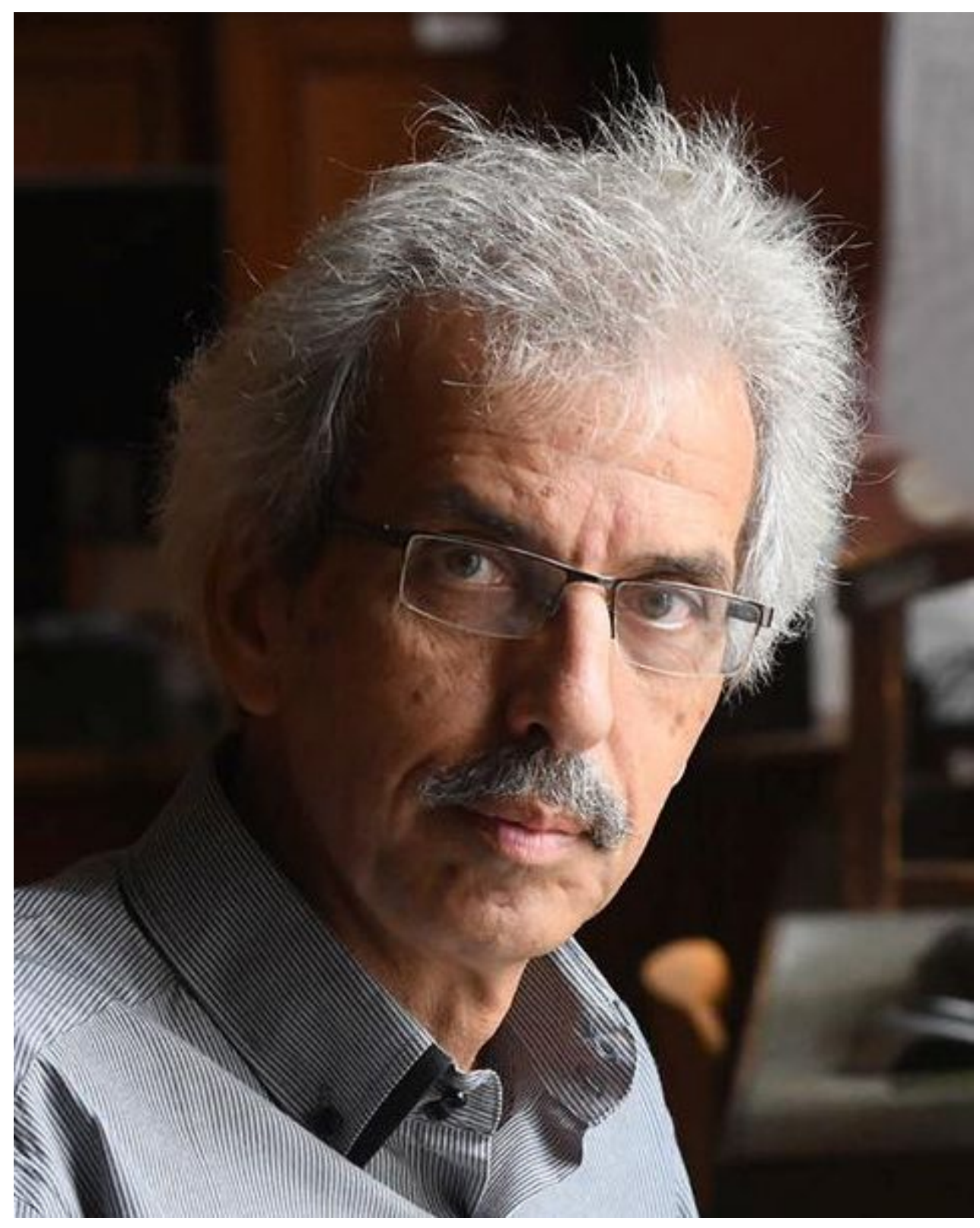

1. ábra. Dr. MerKL OtTó a Magyar Természettudományi Múzeum Bogárgyüjteményében, 2018-ban (REviczKy Zsolt felvétele)

Figure 1. Dr. OTTÓ MERKL in the Coleoptera Collection of the Hungarian Natural History Museum, 2018) (photo by Zsolt REVICZKY) 


\section{Külföldi gyüjtőútjai}

Expedíciói és tanulmányútjai során a következő helyekre jutott el (zárójelben a felkeresett nevezetesebb helyszínek): Üzbegisztán (1981), Örményország (1982), Észak-Korea (Kumgang-san és Paekdu-san) (1988), Kenya (Elgon-hegy és Kenya-hegy) (1992), Indonézia (Gunung Palung Nemzeti Park Nyugat-Borneón) (1993), Malajzia (Cameron-felföld és Tioman szigete) (1995), Laosz (Dong Hua Xao és Phou Khao Kouay) (1998), Taiwan (2002ben kétszer), Nicaragua (2007), Vietnam (2016) és végül Ausztrália (2018) (NÉMETH 2021, SzÉL 2021a). Gyüjtőútjain pihenésre, lazításra nem is gondolt: Laoszban lázas betegen is folytatta a gyüjtést. Ausztráliai expedíciója során vendéglátója a legendás magyar preparátor, zoológus író, HANGAY GYÖRGY volt. Gyüjtéseit még a nagy bozóttüzek előtt végezte, utána ez már aligha lett volna lehetséges (HANGAY 2021). A felsorolt helyekröl többnyire gazdag zsákmánnyal, faunára és tudományra új fajokkal megrakodva tért vissza.

\section{Magyarország bogárfaunájának feltárása}

OTTÓ jelentős szerepet vállalt a hazai bogárfauna feltárásában. A nemzeti parkok kutatása - e gyüjtő-, feldolgozó- és nem utolsósorban szervezést igénylö munka - MERKL OTTÓ múzeumba kerülésének idején már megkezdődött, de a feladat nagyobb része KASZAB ZOLTÁN halála után szinte teljesen rá hárult. A hazai és külföldi szakemberek bevonásával sorban jelentek meg a tanulmányok 1983 és 2002 között a Hortobágyi, a Kiskunsági, a Bükki, az Aggteleki, végül a Fertő-Hanság Nemzeti Parkok bogárvilágáról az Akadémiai Kiadó, később a Magyar Természettudományi Múzeum által kiadott kötetekben.

Részt vett a Bátorligeti Ősláp Természetvédelmi Terület feltárásában is, amely jóval régebbi időkre tekint vissza, mint a nemzeti parkoké: 1953-ban már megjelent egy összefoglaló kötet az élővilágáról. A bogarászati fejezetet KASZAB ZOLTÁN és SzÉKESSY VILMOS írták. A gyüjtéseket a múzeum munkatársai közel 40 év elteltével megismételték, hogy az eltelt időben bekövetkező faunaváltozásokat kimutassák. Bár törekedtek a mintavételezés pontos megismétlésére, az alkalmazott módszerek mégsem tekinthetők a korábbival azonosnak, hiszen a gyüjtők személye változott. A bogarakról szóló fejezet MERKL OTTÓ munkája, melyben nemcsak az új eredményekröl adott számot, hanem a korábban gyüjtött anyagot is ismertette (Reassessment of the beetle fauna of Bátorliget, NE Hungary (Coleoptera)).

A Duna-Ipoly Nemzeti Park Igazgatósága által kiadott Rosalia tanulmánykötetekben a bogarászati fejezetek jó része szintén MERKL OTTó tollából származik. Ilyenek a Szénáshegycsoport (2008), a Naszály (2010), a Duna-Tisza közi homokhátság (2011), a Sas-hegy (2012) és a Turjánvidék (2018) bogárfaunáját tárgyaló cikkek. Terjedelme és az előkerült fajok száma miatt érdemes kiemelni „A Naszály bogárfaunája (Coleoptera)” és „A Sashegy bogárfaunája (Coleoptera)” címü könyvfejezeteket. A Soroksári Botanikus Kert bogárfaunája külön kötetben jelent meg 2019-ben (Biodiverzitás a Soroksári Botanikus Kertben - Bogarak). Az elökerült fajok nagy száma (1446) a gyüjtés és a feldolgozás hatékonyságát bizonyítja. OTTó módszeres, és az ország szinte minden zugára kiterjesztett gyüjtései révén mintegy 160 faunára új bogárfajt mutatott ki Magyarországról, illetve számos kérdéses előfordulású faj elterjedését sikerült tisztáznia (SCHAWALLER 2021). A jelenlegi fajszám meghaladja a 6350 fajt. 


\section{Ismeretterjesztő tevékenysége}

MERKL OTTÓ ismeretterjesztő tevékenysége legalább annyira fontos és hangsúlyos, mint a tudományos. Publikált az Élet és Tudomány, a Természet Világa, a TermészetBúvár, az Állatvilág, a National Geographic Magyarország, a MúzeumCafé, illetve a Honismeret, korábban a Kertészet és Szölészet, a Madártávlat, a Süni, a Süni és a Természet, a Természet, a Vadon, a Magyar Múzeumok, valamint az Interpress Magazin címü lapokban. Az 1996 és 2008 között megjelent Révai Új Lexikona számára több mint 900 állattani címszót írt 250 oldalt is meghaladó terjedelemben. Írásaiban az élvezetes stílus ötvöződik a tudományos pontossággal. Nyomtatásban megjelent népszerüsítő munkáinak száma 137, míg az online írásoké 111.

A VIG KÁROLLYal társszerzőségben írt „Bogarak a pannon régióban” című nagyalakú, közel 500 oldalas könyv 2009-ben a Szép Magyar Könyv versenyen díjat nyert a „Tudományos müvek, szakkönyvek, felsőoktatási kiadványok” kategóriában. E kétszer is kiadott és népszerü kötet a hazai bogárfajok közel egyharmadát mutatja be tudományos hiteleséggel, ugyanakkor közérthetően (MATSKÁsı 2021).

MERKL OTTÓ a társadalom szélesebb rétegeit is érdeklő témákban rendszeresen szakértőként szólalt meg a legkülönfélébb médiumokban, igen gyakran a rádióban és televízióban. 1995 és 2020 között Zootaxonómia tantárgyból gyakorlatot vezetett az Állatorvostudományi Egyetem biológus szakán. Logikusan felépített, érdekes történetekben sem szűkölködő előadásait a hallgatók kifejezetten kedvelték. Népszerü volt a Normafán tartott félnapos terepgyakorlat, melynek során a bogarakon és a gyüjtési módszereken kívül mindenki képet kaphatott a természetismeretről is. OTTÓ szívesen beszélgetett a hallgatókkal, érdeklődéssel fordult feléjük, és minden hallgatói rendezvényen is részt vett. A vizsgákon szigorúan, de emberségesen viselkedett. Tevékeny részt vállalt a múzeumi állandó és számos időszaki kiállítás forgatókönyvének elkészítésében, a szakmai anyag lektorálásában, és nagyon gyakran a kiállítás létrehozásában is.

\section{Fordítás, lektorálás, szerkesztés}

Külön kell szólni MERKL OTTÓ fordítói és lektori tevékenységéröl. A tudományos pálya megkerülhetetlen feladata a lektorálás, de OTTó esetében ez kivételesen nagy súllyal szerepel. Hazai és külföldi szakemberek munkáit egyaránt átnézte, lektorálta, a magyar nyelvüeket nyelvi szempontból is javította. Múzeumi pályafutásának első felében több száz angol nyelvü, zoológiai témájú ismeretterjesztő filmet fordított vagy lektorált, míg az állattani könyvek fordítása és lektorálása szinte egész életét végigkísérte - az ilyen könyvek száma bőven meghaladja a százat. Bár legszívesebben rovartani tárgyú müveket fordított, az általa gondozott könyvek és filmek valójában a zoológia szinte valamennyi területét felölelik.

A szerkesztői feladatokból is alaposan kivette a részét. 1989 és 1994 között a Folia entomologica hungarica folyóirat segédszerkesztője, 2005 és 2020 között szerkesztője. 1991 és 2015 között a múzeum saját lapjának, az Annales historico-naturalis Musei nationalis hungarici-nek a szerkesztője. 2008 és 2017 között a Stuttgarter Beiträge zur Naturkunde (később Integrative Systematics) szerkesztőbizottsági tagja. Szerkesztői ars poeticáját a kérlelhetetlen pontosság és szigorúság, ugyanakkor az őszinte segítőkészség jellemezte. 


\section{Kapcsolata a Magyar Rovartani Társasággal}

A Magyar Rovartani Társaságnak 1978-tól tagja, 1985-től választmányi tagja, majd 1995-töl haláláig alelnöke. Meghatározó személyiség volt ebben a szerepkörben is, aki szinte az összes ülésén jelen volt. A pályamunkák, fotók bírálatában mindig aktívan részt vett. Már a kezdetektől, 2011-től a szívén viselte az „Év rovara” kampányt, melynek során a Magyar Rovartani Társaság három rovarfajt nevez meg, majd internetes közönségszavazatok döntik el, hogy melyik faj lesz a nyertes közülük. Ezt követően az év rovaráról egy nagyobb lélegzetü online megjelenés után számos lap beszámol, így többek között az Élet és Tudomány, a Természet Világa, a TermészetBúvár, a Honismeret. Ha az év rovara bogár volt, akkor az összes szervezői és szakírói tevékenységet OTTó végezte, de ha a nyertes más rovarcsoportból került ki, akkor is jelentősen hozzájárult a munkák kivitelezéséhez. A mozgalom 10 éves évfordulójára 2020-ban „Tíz év rovarai” címmel megjelent egy fotókkal gazdagon illusztrált kiadvány OTTó és DEDÁK DALMA szerkesztésében, amelyben az addigi Év rovarai vonultak fel. Halálának hetében választották volna a Társaság elnökévé.

\section{Kitüntetései}

A Magyar Biológiai Társaságnak 1992-től tagja. A Magyar Rovartani Társaság Frivaldszky Imre Emlékplakettjének bronz fokozatát 1993-ban, arany fokozatát 2019-ben nyerte el. Ezt a kitüntetést ilyen fiatalon korábban senki sem kapta meg. 2019-ben Pro Natura Díjat kapott a tudományos életben több mint két évtizede tanúsított kiemelkedő munkájáért, a magyarországi rovarvilág, különösen a bogárfauna védelmében, népszerüsítésében nyújtott teljesítményéért, az állami természetvédelmet segítő tevékenységéért.

2021. február 19-én halt meg Budapesten a csepeli HÉV megállójában szívroham következtében, amikor reggel munkába indult.

\section{Irodalomjegyzék}

HANGAy Gy. 2021. Ottóra emlékezve. Rovarász Híradó 101: 9-12.

MATSKÁsI I. 2021: Búcsúbeszéd Merkl Ottó ravatalánál. Rovarász Híradó 101: 3-5.

NÉMETH T. 2021: Mesterem és kollégám. Rovarász Híradó 101: 13-19.

SCHAwALleR W. 2021. Obituary. In Memoriam: Dr. Ottó Merkl (1957-2021), Budapest. Integrative Sytematics: Stuttgart Contributions to Natural History 4(1); published online 30.VI.2021; DOI: 10.18476/2021.302448 (utolsó hozzáférés: 2021. november 22.).

SzÉL Gy. 2021a. In memoriam Merkl Ottó (1957-2021). https://mttmuzeum.blog.hu/ 2021/02/25/in_memoriam_merkl_otto_1957 (utolsó hozzáférés: 2021. november 22.).

SzÉL Gy. 2021b. Emlékezés Merkl Ottóra (1957-2021). Növényvédelem 82(4): 178-181.

VIG K. 2020. In memoriam Ottó Merkl (1957-2021). Folia entomologica hungarica 81: 7-9.

VIG K. 2021. Búcsúbeszéd Merkl Ottó ravatalánál. Rovarász Híradó 101: 3-5. 


\section{Válogatás Dr. MERKL OTTó munkáiból Selected works of Dr. OTTó MERKL}

MerkL O. 1991. Reassessment of the beetle fauna of Bátorliget, NE Hungary (Coleoptera). In: MAHUnKA S. (ed.): The Bátorliget Nature Reserves - after forty years. Hungarian Natural History Museum, Budapest, pp. 381-498.

MerkL O. \& Vig K. 2009. Bogarak a pannon régióban. [Beetles in the Pannonian Region.] Vas Megyei Múzeumok Igazgatósága, B. K. L. Kiadó, Magyar Természettudományi Múzeum, Szombathely, $494 \mathrm{pp}$.

MerkL O. 2010. A Naszály bogárfaunája (Coleoptera). (Beetles (Coleoptera) of Mt Naszály (Hungary).) In: Pintér B. \& TímÁR G. (szerk.): A Naszály természetrajza. Tanulmánygyüjtemény. (A natural history of Mt Naszály, Hungary.) Rosalia (A Duna-Ipoly Nemzeti Park Igazgatóság tanulmánykötetei, 5.) Duna-Ipoly Nemzeti Park Igazgatóság, Budapest, pp. 533-639.

MerkL O. \& SzÉL Gy. 2012. A Sas-hegy bogárfaunája (Coleoptera). (Beetles (Coleoptera) of Mt Sashegy (Budapest, Hungary).) In: KéZDY P. \& TóTH Z. (szerk.): Természetvédelem és kutatás a budai Sas-hegyen. Rosalia (A Duna-Ipoly Nemzeti Park Igazgatóság tanulmánykötetei, 8.) DunaIpoly Nemzeti Park Igazgatóság, Budapest, pp. 373-458.

Merkl O., Grabant A. \& Soltész Z. 2015. A Magyar Természettudományi Múzeum gyászbogártípusainak (Tenebrionidae) katalógusa. (Type catalogue of darkling beetles (Tenebrionidae) preserved in the Hungarian Natural History Museum.) Magyar Természettudományi Múzeum, Budapest, 735 pp.

Merkl O., SzalóKi D., KuTAsi Cs., MÉsZÁRos Á., Podlussány A. \& TAllósi B. 2019. Biodiverzitás a Soroksári Botanikus Kertben - Bogarak. (Biodiversity in the Soroksár Botanical Garden Beetles.) Magyar Biodiverzitás-kutató Társaság \& SZIE Kertészettudományi Kar, Soroksári Botanikus Kert, Budapest, 179 pp.

Merkl O., Paulovkin A., Puskás G., Szél Gy., Tóth B., VÁsárhelyi T. \& Vig K. 2020. Tíz év rovarai. [Insects of ten years.] Magyar Rovartani Társaság, Budapest, 104 pp.

Bouchard P., Bousquet Y., Aalbu R.L., Alonso-Zarazaga M.A., Merkl O. \& Davies A.E. 2021. Review of genus-group names in the family Tenebrionidae (Insecta: Coleoptera). ZooKeys 1050: $1-633$. 


\section{In memoriam Dr. OTTó MERKL (1957-2021)}

\section{GYőZő SZÉL}

Department of Zoology, Hungarian Natural History Museum, Baross utca 13, H-1088 Budapest, Hungary E-mail: szel.gyozo@nhmus.hu

ÁLLATTANI KÖZLEMÉNYEK (2021) 106(1-2): 000-000.

Abstract. OтTó MeRKL worked from 1 September 1981 until his death on 19 February 2021 in the Hungarian Natural History Museum, his first and only employment; from 1985 he was lead curator of the Coleoptera Collection in the Department of Zoology, from 12 February 2021 as head of that department. One of his most important challenges was the modern and up-to-date curation of the collection and improving the percentage of identified specimens; at the same time increasing the species number by collecting and exchanges and promoting the use of the material. During his career he described 164 species and subspecies new to science, mostly belonging to Tenebrionidae and in revisional works he also named 18 genus-group taxa. He had 248 scientific publications, 137 articles of popular science in printed media and 111 online articles. 